\title{
TRANSFORMATION OF THE TOURISM SECTOR IN SOUTH AFRICA: A POSSIBLE GROWTH STIMULANT?
}

\author{
Diane ABRAHAMS ${ }^{*}$ \\ University of Johannesburg, School of Tourism and Hospitality, \\ College of Business and Economics, South Africa, e-mail: dabrahams@uj.ac.za
}

\begin{abstract}
Citation: Abrahams D. (2019). TRANSFORMATION OF THE TOURISM SECTOR IN SOUTH AFRICA: A POSSIBLE GROWTH STIMULANT? GeoJournal of Tourism and Geosites, 26(3), 821-830. https://doi.org/10.30892/gtg.26312-400
\end{abstract}

\begin{abstract}
Transformation is regarded as a national imperative in South Africa to deal with the inequalities of the past. Several pieces of legislation, policies and codes have been instituted to drive the process in the country. The question, however, remains whether the transformation process has resulted in a compliance culture or if indeed it is aspirational in driving change that is forward thinking, innovative and truly all inclusive. The travel and tourism sector is a sector that can provide access to the economy for many in terms of job creation and entrepreneurial opportunities. In South Africa, the National Tourism Sector Strategy (NTSS) which provides a blueprint for the tourism sector, places transformation at the centre of the changes required to grow the sector. The aim of the paper is to analyse the transformation processes underway in the tourism sector in South Africa and the impact that this may have had on promoting growth and access in the sector. In terms of international tourism scholarship this paper debates a distinctive dimension of the tourism sector in South Africa, namely the processes and progress around transformation.
\end{abstract}

Key words: transformation, tourism, inclusive development, economic development, South Africa

\section{INTRODUCTION}

Globally there is much debate around the concept and attainment of pathways of 'inclusive and sustainable growth'. In the case of South Africa for inclusive and sustainable economic growth to take place it requires the making of an economy that meets the needs of all its people in an equitable manner (World Bank, 2018). Despite some success with a broad range of state policy, strategy and programme interventions aimed at overcoming economic disparities it remains that entrenched inequalities continue to characterise the South African economy. It is argued that such structural inequalities continue act as a deterrent to growth, economic development, employment creation and the eradication of poverty (DTI, 2015). These inequalities are defined in terms of racial and gender biases in the distribution of and access to wealth, income, skills

\footnotetext{
* Corresponding author
} 
and employment. As a whole the National Treasury (2019) demonstrates that the South African economy continues to perform below its full potential and with its entrenched inequalities further marginalises the lives of those on the periphery (DTI, 2015).

For Turok \& Visagie (2018) the concept of inclusive development is a seductive idea that a more dynamic and productive economy can go hand-in- hand with reduced inequality and exclusion. In the case of South Africa, a stagnant economy plagued by high levels of unemployment and growing levels of inequality makes this notion of inclusive development more challenging and elusive. Transformation of the economy will demand more than a compliance culture and the kind of innovation that will result in visible changes to improve the lives of the majority of South Africans. Since 2014 South Africa has seen a marked decline in economic growth with a technical recession recorded during the first half of 2018 (RSA, 2018; National Treasury, 2019). The country's Inaugural Jobs Summit in 2018 rightfully placed the urgent need to address joblessness and the stimulation of greater participation in the economy at the forefront. Redress is an important tool to transform an economy in which the majority of the population under apartheid were purposefully restricted from meaningful participation in the mainstream economy. The South African government's comprehensive policies and strategy around Broad Based Black Economic Empowerment (BBBEE) is the vehicle that has this transformative imperative for dealing with the apartheid legacy.

The tourism sector in South Africa is viewed by national government as a critical sector for the transformation of the national economy (Rogerson, 2004a; Nyazema, 2013; National Treasury, 2019). In addition, national government considers that the labour-absorptive tourism sector has great potential for further job creation and enterprise development - especially for small, medium and micro-enterprises (SMMEs) which in turn will address the distressingly high levels of unemployment. However, it is argued in order for the tourism sector to growth and contribute positively to economic growth and employment targets that issues around access and transformation need to be addressed. Several recent papers have examined questions around 'access' and inclusion into the tourism economy of entrepreneurs from disadvantaged groups under apartheid (Adinolfi et al., 2018; Harilal \& Nyikana, 2019; Rogerson \& Rogerson, 2019a, 2019b). The aim of this paper is extend this scholarship by analysing the transformation processes underway in the tourism sector in South Africa. In particular, the analysis focuses on the impact that this may have had on promoting growth and access in the sector and explores whether the transformation policies and strategies have had any meaningful impact and change through the engagement of key stakeholders in the sector.

\section{HISTORICAL CONTEXT TO TRANSFORMATION INITIATIVES IN SOUTH AFRICA}

Across the international experience several countries have implemented strategies similar to those recently enacted in South Africa in order to address its transformation objectives. Indeed, it is evident that in terms of the policies of B-BBEE South Africa has derived its learning from several global cases on the implementation of affirmative action policies (Jain et al., 2003; Jain et al., 2012; Nyazema, 2013). Indeed, several countries, including the United States of America, India, Malaysia, Canada, Australia and Brazil have faced similar challenges of racial, ethnic or gender discrimination, socio-economic inequality and implemented policies to deal with such inequalities (Cahn, 2002; Crosby, 2004; Sowell, 2004; Telles, 2004; Kellough, 2006; Nyazema, 2013).

The promotion of the SMME economy was identified as an important vehicle for achieving transformation objectives by the national government after South Africa's democratic transition in 1994 (Rogerson, 2004b). In 1995, a national strategy for the 
development and promotion of small business in South Africa was tabled in Parliament. The creation of new black-owned and black-controlled enterprises was seen as a key component of the strategy. The National Small Business Act was introduced in 1996 to provide an enabling environment for small, medium and micro-enterprises (SMMEs) and to establish several institutions to provide financial and other support to entrepreneurs.

These new institutions - Khula and Ntsika - targeted substantial proportions of their programmes at black entrepreneurs. In 1997, government issued a Green Paper on public sector procurement reform (Rogerson, 2004b). This policy document recognised that government, as the largest buyer of goods and services in the economy, had the responsibility to leverage this purchasing power in support of its economic policy objectives of broad-based black economic empowerment, small enterprise development, and labour-intensive construction (DTI, 2001). In 1998 further important pieces of legislation were enacted to address the objectives for broad-based black economic empowerment. These included, amongst others, the Competition Act, 1998, which aimed to expand the numbers of historically disadvantaged persons with an ownership stake in the economy. The Act allows for exemptions from the provisions on anti-competitive practices where such practices promote the ability of black-owned and-controlled enterprises to become competitive (DTI, 2001). The Employment Equity Act (1998) was another an important piece of legislation that outlawed all forms of unfair discrimination at work and required all enterprises employing more than fifty employees to take affirmative action to bring about a representative spread of designated groups in all occupations and organisational levels within defined time periods (DTI, 2001).

In addition, the National Empowerment Fund (NEF), a trust established in 1998 to hold equity stakes in state-owned enterprises and other private enterprises on behalf of historically disadvantaged persons. The NEF Corporation, established in terms of the NEF Act, 1998, was tasked to provide historically disadvantaged persons with the opportunity to both directly and indirectly acquire shares; encourage and promote savings, investment and meaningful economic participation by historically disadvantaged persons; and, to promote and support business ventures pioneered and run by historically disadvantaged persons (DTI, 2001). Government provided financial support in various form over the years in support of BEE. Enterprise support was provided through agencies such as Ntsika and Khula initially- later the Small Enterprise Development Agency (SEDA) as well as the Industrial Development Corporation (IDC). Other support was offered through the Land Bank, Development Bank of Southern Africa and special funds such as the Isibaya Fund and the Umsombomvu Youth Fund (DTI, 2001).

\section{DEFINING BROAD-BASED BLACK ECONOMIC EMPOWERMENT}

At the outset of South Africa's policies for BBBEE was the critical issue of definition. The core challenge in defining black economic empowerment was to find the appropriate balance between on the one hand a very broad definition and on the other hand an overly narrow one. If BEE was defined too broadly it would be equated with economic development and transformation in general, which is commensurate with the totality of government's programme of reconstruction and development. Nevertheless, if BEE were defined too narrowly it would be limited to a set of transactions about transferring corporate assets from white to black ownership (DTI, 2015).

It is for this reason that the South African government defines BEE as an integrated and coherent socio-economic process that directly contributes to the economic transformation of South Africa and brings about significant increases in the numbers of black people that manage, own and control the country's economy, as well as significant decreases in income inequalities (Republic of South Africa, 2004). The main purpose of 
Black Economic Empowerment is to ensure the following: (i) a substantial increase in the number of black people who have ownership and control of existing and new enterprises; (ii) a significant increase in the number of new black enterprises, black-empowered enterprises and black-engendered enterprises; (iii) a significant increase in number of black people in executive and senior management of enterprises; (iv) increased ownership of land and other productive assets, improved access to infrastructure, increased acquisition of skills, and increased participation in productive economic activities; Increased income levels of black persons and a reduction of income inequalities between and within race groups (DTI, 2001 ). The aim of government was then to measure the progress towards achieving these objectives. To this end several policy instruments were put in place and government encouraged partnerships with the private sector in order to accelerate BEE. The introduction of BEE Codes of Practice, Balanced Scorecard and the BEE Advisory Council were all tools to measure the progress of this important transformation aspect. The aim of the scorecard, which set a number of measurable targets, was to track progress in terms of several critical indicators, inter alia, (i) direct empowerment through ownership and control of enterprises and assets; (ii) human resource development and employment equity; and (iii) indirect empowerment through preferential procurement and enterprise development. The scorecard further allowed for government departments, state-owned enterprises, and other public agencies, to align their own procurement practices in support of BEE (DTI, 2001).

Notwithstanding the significance of transformation for the South African economy the existing literature on the topic remains relatively limited and is mainly concentrated upon political debates (Southall, 2007; Fauconnier \& Mathur-Helm, 2008; Tangri \& Southall, 2008). Specific industry experiences for example in the mining, agriculture and banking sector have been documented (Booysen, 2007). The critics of B-BEE argue that it has dealt black entrepreneurship a fatal blow and instead that it has created a small Black elite (Kruger, 2011). A review on the impact of BEE on the performance of South African businesses, revealed that perceptions are mostly negative with few (white-owned) companies seeing any benefits in terms of inter alia global competitiveness, service quality, financials, or production performance (Kruger, 2011). Luiz (2002) contends that it should not be the State that takes the lead role in enabling growth of small businesses in South Africa but rather the country's capable and established large private sector.

The only concern highlighted is that large firms choose to form linkages with SMMEs solely for cosmetic purposes and to improve their BEE credentials. Accordingly, there is therefore no real transformation taking place. Overall, there is recorded a widespread mistrust between the public and private sector in South Africa. Turok \& Visagie (2018) looked at the kind of trade-offs that will be needed for true transformation and for inclusive development to take place in the country. Booyens (2011) suggested that SMMEs tend to not form strong upward linkages with larger firms, thus denying opportunities for development and recommended encouraging government to grow the 'knowledge networks'. In one of the few studies examining transformation in the tourism and hospitality sector. Nyazema (2013) indicated that less than $25 \%$ of hotels in South Africa purchased products and services from small black suppliers. Hotel group policy influenced procurement decisions in nearly 80 per cent of establishments. The factors influencing the low investment in assisting and growing black enterprises included hotel general managers' lack of confidence in the capacity and ability of small black enterprises to supply required goods and services. From the extant findings around transformation it appears that the objective of inclusive growth might be elusive.

Overall, Turok \& Visagie (2018) argue that for inclusive development it is necessary to combine different kinds of enterprising activities with the sharing of resources and 
expertise. Inclusive development is viewed as the key to transforming the economy and it is about social processes and the dynamics of change - not simply about distributional outcomes (Turok \& Visagie, 2018). Of critical importance is the need to recognise the role of human agency in transformation. People will shape the change and their experiences can contribute to socio-economic development. This said, the question remains whether it is possible to reform or transform an economy without undermining its existence (Turok \& Visagie, 2018). There is indeed a fine balance between expanding opportunities and steering the economy along a specific development trajectory - so that it becomes both more equitable and inclusive over time (Turok \& Visagie, 2018).

A core question arises about who is responsible for this - government and/or private sector? Public and private sector complementarities may be the way to move forward on this but the relationship building to deal with the mistrust could hinder progress. It is against this backdrop of national debates around the meaning and directions of economic transformation in South Africa that attention turns in the next section of material to explore in detail the specific issues surrounding the tourism sector. As has been highlighted in South Africa's national tourism strategy, the sector of tourism is viewed as embodying great potential to assist in dealing with the large scale unemployment; could assist in driving the SMME development as well as providing opportunities for youth employment as well as entrepreneurs (Department of Tourism, 2018).

\section{BLACK ECONOMIC EMPOWERMENT AND TOURISM}

The beginnings of transformation measures in South Africa's tourism sector must be traced back to 2003 when the South African government promulgated the BroadBased Black Economic Empowerment Act No. 53 to establish a legislative framework for the promotion of Black Economic Empowerment in the country (Republic of South Africa, 2004). The Act made provision for the development of the Codes of Good Practice and establishment of the Sector Charters. One of the first Sector Charters was the Tourism BBBEE Charter which was developed in 2005 and signed as a commitment by all stakeholders in the tourism sector for the empowerment, transformation and collaboration to ensure that the opportunities and benefits of tourism are also extended to Black South Africans who previously were not allowed under apartheid to participate as entrepreneurs in the mainstream tourism economy (NDT, 2005). In May 2009, the Tourism B-BBEE Sector Code was gazetted with the further purpose of promoting the increased broad-based and effective participation of black people in the economy.

The legislative enforcement of the transformation agenda continued. In October 2013 all sector Charter Councils were required to align and gazette their specific Sector Codes under Section nine (9) of the B-BBEE Amendment Act No. 46 of 2013. To this end, for the tourism sector, the Tourism B-BBEE Charter Council gazetted the Amended Tourism B-BBEE Sector Code in line with the Amended Generic Codes of Good Practice in November 2015. The compliance targets of the Tourism Code (as amended) have been revised in consultation with stakeholders in the tourism sector.

The implementation of these codes is monitored by the Tourism BEE Charter Council but the actual impact of transformation of the tourism sector is yet to be realised. During 2019 a newly elected Tourism BEE Charter Council was appointed by the Minister of Tourism. Two main challenges face the tourism sector in South Africa, namely, (i) the need to become more globally competitive; and (ii) the need to include black people in the tourism sector (DTI, 2015). There is broad recognition by the South African government that the two challenges are interlinked. The commitment to transformation and empowerment is emphasized in the Amended Broad Based Black Economic Empowerment Codes 2015 which were issued by the National Department of 
Trade \& Industry (DTI, 2015). Addressing these issues will not only result in the growth of the tourism sector but the overall expansion of the South African economy.

In the Amended Codes the focus is issues of on Ownership, Management Control, Skills Development, Enterprise and Supplier Development as well as SocioEconomic Development (DTI, 2015). The National Tourism Sector Strategy (NTSS) is a further statement of the importance of tourism to drive growth and employment in South Africa. The NTSS was reviewed 2015 and core to the revisions is the transformation of the sector (Department of Tourism, 2018). It is acknowledged that without this committed drive to broaden the base and benefits of the tourism sector, generally the tourism benefits often do not filter down to poor communities or bring about economic development and the structure of South Africa's tourism economy will continues to be dominated by a small group of large, mostly white-owned tourism organisations (see Rogerson, 2005). South Africa's national Department of Tourism has commissioned several studies on the sub sectors of the tourism industry - realizing that the pace of change and inclusion was slow (see Rogerson \& Rogerson, 2019a, 2019b).

The Broad Based Black Economic Empowerment policy is the national government's response to accelerate the inclusion into economic activity of black people who were previously disadvantaged. The pace of BBBEE implementation in the private sector, including the tourism sector, is regarded as slow and needs to accelerate. The Amended Tourism B-BBEE Sector Code applies to all enterprises within the Tourism Sector and all parts of the value chain in that sector, inter alia: accommodation (hotels, guest houses, resort properties and timeshare, game lodges, backpackers and hostels and bed and breakfast (B\&B's); hospitality \& related services (restaurants and conference venues that are not attached to hotels, professional catering); attractions; casinos; consulting and professional services; travel and related services (including tour wholesalers, tour operators, travel agents, tourist guides, car rental companies and coach operators) (Department of Tourism, 2016). The 5 elements in B-BBEE scorecard which impact tourism enterprises are as follows:

(i)Ownership;

(ii) Management Control;

(iii) Skills Development;

(iv) Enterprise and supplier development; and

(v) Socio-economic development.

Table 1. B-BBEE Recognition Levels (Data source: Department of Tourism, 2016)

\begin{tabular}{|l|c|c|}
\hline \multicolumn{1}{|c|}{ B- BBEE Status } & Qualification & Recognition Level \\
\hline Level One Contributor & 100 points on the Scorecard & $135 \%$ \\
\hline Level Two Contributor & 95 but $<100$ points on the Scorecard & $125 \%$ \\
\hline Level Three Contributor & 90 but $<95$ points on the Scorecard & $110 \%$ \\
\hline Level Four Contributor & 80 but $<90$ points on the Scorecard & $100 \%$ \\
\hline Level Five Contributor & 75 but $<80$ points on the Scorecard & $80 \%$ \\
\hline Level Six Contributor & 70 but $<75$ points on the Scorecard & $60 \%$ \\
\hline Level Seven Contributor & 55 but $<70$ points on the Scorecard & $50 \%$ \\
\hline Level Eight Contributor & 40 but $<55$ points on the Scorecard & $10 \%$ \\
\hline Non-Compliant Contributor & 40 points on the Scorecard & $0 \%$ \\
\hline
\end{tabular}

The three priority elements with the highest weighting in the scorecard are ownership, where the sub-minimum is $40 \%$ of net value; skills development and enterprise development. Large enterprises have to comply with three of these priority elements and qualifying small enterprises with two of the three priority elements. Based on 
their overall performance of the entity during verification, a B-BBEE status with a corresponding B-BEE recognition level will be given to the entity (Department of Tourism, 2016). Table 1 provides full details of classification of enterprises by B-BBEE status.

The process of verification of tourism enterprises for B-BBEE compliance is performed by a Verification Professional of a Verification Agency. The B-BBEE Verification Professional Regulator is appointed by the Minister of Trade and Industry and is accredited for tourism (NDT, 2016). In addition there is a Tourism B- BEE Charter Council to monitor transformation and compliance with the codes. The Council is appointed by the Minister of Tourism and represents the different relevant constituencies in tourism such as large and small enterprises, tourism associations, academics, labour and civil society. The primary roles of the Council are the following:

1. Provide guidance on sector specific matters effecting B-BBEE in entities within the sector;

2. Compile reports on the status of B-BBEE within the sector; and

3. Monitor the implementation of the Amended Tourism B-BBEE Sector Code (Department of Tourism, 2016).

Given the regulation and monitoring processes that are in place, the question is what would a transformed tourism industry look like in South Africa Saunders (2018) argues that it would be one in which most enterprises across the spectrum are blackowned and that in all enterprises black people feature strongly at all levels including the Board and executive, management, supervisory levels as well as at skilled and unskilled levels. The spectrum of tourism establishments includes small, medium and large enterprises; rural as well as urban enterprises; budget, midmarket as well as luxury enterprises and those enterprises that serve domestic and/or international markets; in other words all the sub-sectors of the South African tourism industry (Saunders, 2018).

A transformed sector would be one in which communities are included and the benefits of tourism growth flow to marginalised and adjacent communities. In addressing a Tourism Leadership dialogue Saunders (2018) noted that a transformed sector is "when we stop counting and measuring, then we will know we got there". This said, Khumalo (2019) maintains business in South Africa essentially reacts to regulation and not to prompts to 'do the right thing'. Furthermore Khumalo (2019) notes that regulators are getting smarter about empowerment and that the amendments to the B-BBEE codes where the notion was that big companies would essentially obtain level 1or level 2 status because of their black shareholding, as instead seen regulators getting smarter about BBBEE. The amendments to the B-BBEE codes also sends the wrong message that successful black people have no part to play in empowering other black people (Khumalo, 2019). An important clause in the amended B-BEE codes is where large corporations will be alaowed to earn 1.2 times the procurement points if they spend with businesses that are more than $51 \%$ black-owned (Khumalo, 2019). This bodes well for transformation as it gives black business a competitive edge that would aid in addressing the racial exclusion which is still in evidence in the South African economy (World Bank, 2018).

The ideal of a transformed tourism sector is one that would emphasise inclusivity and empowerment in every dimension. In order to achieve the desired outcome of a transformed sector certain critical issues need to be addressed by those in leadership in the sector. The two critical issues are ownership (sustained and successful) and skills (real and relevant). For ownership matters to be addressed in the sector attention has be given to (i) access to markets and distribution; (ii) access to finance; (iii) red uction of red tape and, (iv) innovation (Saunders, 2018). In terms of skills, the focus needs to be on skills that are relevant in terms of the market needs; skills that ensure employability; and where skills development takes place through youth employment programmes with 
appropriate apprenticeships and internships that would aid work place experience. Further, the focus on skills should also be on both quantity and quality of skills in the sector as well as the type of skill (Saunders, 2018).

Finally, inclusivity in the South African tourism sector would translate into increasing the involvement of black people as customers, from all income groups, and being able to book, access, feel comfortable and enjoy a tourism product that meets their needs in all sub-sectors of the industry (Saunders, 2018).

The question is whether transformation therefore, with all that has been said around skills, inclusivity, empowerment and opportunity, indeed be a stimulant for growth in the tourism sector? It is implied that the above discussed aspects of change can aid the tourism sector to grow to its full potential as they would result in more participants owning and using the products of tourism. This, however, remains to be seen as transformation continues at a slow pace in the country despite the plethora of amendments made to codes and regulations in order to catalyse transformation.

Critics of B-BBEE assert that it brings about only marginal change which is at the expense of economic growth and further that it places additional costs and regulation on business (Khumalo, 2019). The recent amendments to the B-BBEE codes have embraced aspects of skills development, enterprise and supplier development and thereby the notion of change beyond redistribution and indeed changes aimed at stimulating economic activity through increasing the South African economy's productive capacity and nurturing entrepreneurship (Khumalo, 2019).

The current status on transformation shows that there is need for breakthrough strategy for compliance. Procurement patterns in the private sector show limited transformation and there is therefore an urgent need to review the model for measuring corporate compliance. It is encouraging that large corporations can now issue a large five year contract to an SME, provide it with development support and enjoy full compliance benefits (Khumalo, 2019). The most recent B-BBEE amendments recognise that corporations are now able to claim B-BEE points for the development support that they provide to small businesses even if that business grows into a large business during that period. Finally, it is widely acknowledged that in order to accelerate transformation government needs itself to drastically improve its own procurement spend and payments made to SMMEs (World Bank, 2018; National Treasury, 2019).

The overall policy focus remains on Small, Medium and Microenterprises (SMMEs) and yet it has been shown that the linkages these have with big business in the value chain remains limited (Adinolfi et al., 2018). Going forward it is evident that the role of government as an enabler and facilitator of economic development versus its role as regulator for compliance needs to clarification (Department of Tourism, 2017). Further, it has been recommended that government and the private sector should establish a fund through contributions from Enterprise \& Supplier Development (ESD) and Socio-Economic (SED) elements to finance new entrants into the market, including existing black businesses for expansions (NDT, 2017). Innovation, and training remain important issues also for the future growth of the sector most especially in the wake of new technology and industry disruptors such as Airbnb (Department of Tourism, 2017).

\section{CONCLUSION}

In terms of international tourism scholarship this paper analyses a distinctive dimension of tourism in South Africa, namely the debates, processes and progress around transformation. Arguably, there is still a long way to go both in terms of transforming the country's tourism sector and of growing it to its full potential. It is evident that current practices surrounding transformation appear mostly about measuring compliance and 
that this results in limited overall change in the sector despite the push with legislation and for monitoring compliance requirements. The B-BEE Council is tasked to deal with those companies that do not comply with the Codes. It can be stated that private sector organisations, like the Tourism Business Council of South Africa, need to play a stronger lead role - together with their members - in improving the pace of transformation of the sector as this would, in turn, grow the size and opportunities within it. In addition, there is a definite need to broaden the awareness of industry stakeholders that the sector is more sustainable if more people are empowered and included. For transformation to be successful it is evident there is a need for both a willing heart and mind and that as much as compliance is important in that it will assist in fast tracking the much-needed change, the afore-mentioned will go a long way in effecting more sustainable and impactful changes in the sector. In terms of contemporary debates about the national economy tourism is viewed as a 'game changer' as it can assist with youth unemployment and provide a range of entrepreneurial opportunities (National Treasury, 2019).

With a supportive enabling environment the tourism sector can expand to its full potential and assist to address the core socio-economic challenges that the South African economy currently faces. The South African adage of to 'BEE or not to BEE' - is clearly no longer the question, as sustainable black economic empowerment is the core to the changes required for the sector to grow. The question that does, however, remain is rather how the broader benefits and impact of B-BEE can help expand the sector and to grow the economy. This issue needs further research from tourism scholars as national government continues to strive for more inclusive and equitable development.

\section{Aknowlegments}

An earlier version of this paper was presented at the International Geographical Union Conference, Quebec City, August 2018. Thanks go to the University of Johannesburg for funding and to Skye Norfolk for editorial inputs.

\section{REFERENCES}

Adinolfi, M.C., Jacobs, M., \& Tichaawa, T.M. (2018). Unpacking Factors Limiting and Promoting BlackOwned SMMEs to Participate Actively Within the Tourism Value Chain in South Africa. Africa Insight, 48 (3), 88 -104.

Booyens, L. (2007). Barriers to Employment Equity Implementation and Retention of Blacks in Management in South Africa. South African Journal of Labour Relations, 31(1), 47-71

Booyens, I. (2011). Are Small, Medium, and Micro-sized Enterprises Engines of Innovation? The Reality in South Africa. Science and Public Policy, 38(1), 67-78.

Cahn, S.M. (2002). Ed. The affirmative action debate. New York: Routledge.

Crosby, F.J. (2004). Affirmative action is dead: Long live affirmative action. New Haven: Yale University Press.

Fauconnier, A. \& Marthur-Helm, B. (2008). Black economic empowerment in the South African mining industry: A case study of Exxaro Limited. South African Journal of Business Management, 39(4), 1-14.

Jain, H.C., Sloane, P.J. \& Horwitz, F.M. (2003). Employment equity and affirmative action: An international comparison. New York: Sharpe Inc.

Jain, H.C., Horwitz, F. \& Wilkin, C.L. (2012). Employment equity in Canada and South Africa: A comparative review. The International Journal of Human Resource Management, 23(1), 1-17.

Harilal, V. \& Nyikana, S. (2019) Factors Inhibiting Large Enterprises From Establishing Sustainable Linkages With Black-Owned SMMEs in South Africa. African Journal of Hospitality, Tourism and Leisure, 8 (3), 1-14.

Kellough, J.E. (2006). Understanding affirmative action: Politics, discrimination and the search for justice. Washington: Georgetown University Press.

Kruger, L.P. (2011). The Impact of Black Economic Empowerment (BEE) on South African Business: Focusing on the Dimensions of Business Performance. Southern African Business Review, 15(3), 207-233

Khumalo, A. (2019). A Sign that Regulators are Getting Smarter About Empowerment. Business Times, 16 June.

Luiz, J. (2002). Small Business Development, Entrepreneurship and Expanding the Business Sector in a Developing Economy: The Case of South Africa. Journal of Applied Business Research, 18(2), 53-68. 
Nyazema, M.M. (2013). Developing an Empowerment Framework for Broad-based Black Economic Empowerment in the Hotel Industry of South Africa. PhD dissertation (Business Management and Administration), Stellenbosch University, Stellenbosch.

Rogerson, C.M. (2004a). Black economic empowerment in South African tourism. In C.M. Rogerson \& G. Visser, (Eds.), Tourism and Development Issues in Contemporary South Africa, Pretoria: Africa Institute of South Africa.

Rogerson, C.M. (2004b). The Impact of the South African Government's SMME Programmes: A Ten Year Review. Development Southern Africa, 21, 765-784.

Rogerson, C.M. (2005). Unpacking Tourism SMMEs in South Africa: Structure, Support Needs and Policy Response. Development Southern Africa, 22, 623-642.

Rogerson, C.M. \& Rogerson, J.M. (2019a). Public Procurement, State Assets and Inclusive Tourism: South African Debates. GeoJournal of Tourism and Geosites, 26 (3), 686-700.

Rogerson, C.M. \& Rogerson, J.M. (2019b). Tourism, Local Economic Development and Inclusion: Evidence from Overstrand Local Municipality, South Africa. GeoJournal of Tourism and Geosites, 25 (2), 293-308.

Saunders, G. (2018). Presentation made at Tourism Leadership Dialogue on Transformation, Johannesburg.

Southall, R. (2007). Ten Propositions About Black Economic Empowerment in South Africa. Review of African Political Economy, 34 (111), 67-84.

Sowell, T. (2004). Affirmative action around the world: An empirical study. London: Yale University Press.

Tangri, R. \& Southall, R. (2008). The politics of black economic empowerment in South Africa. Journal of Southern African Studies, 34(3), 699-716.

Telles, E.E. (2004). Race in another America: The significance of skin color in Brazil. Princeton: Princeton University Press.

Turok, I. \& Visagie, J. (2018). Inclusive Urban Development in South Africa: What Does It Mean and How Can it Be Measured? Brighton, England: University of Sussex Institute of Development Studies Working Paper 512.

*** Department of Tourism. (2013). National Tourism Sector Strategy. Pretoria: Department of Tourism.

*** Department of Tourism. (2016). Easy Guide for the Amended Tourism B-BBEE Sector Code. Pretoria: Department of Tourism.

*** Department of Tourism. (2017). Draft Resolutions of the Tourism Transformation Summit. Pretoria: Department of Tourism.

*** Department of Tourism. (2018). Revised National Tourism Sector Strategy. Pretoria: Department of Tourism.

*** Department of Trade and Industry (DTI). (2001) South Africa's Economic Transformation: Strategy for Broad Based Black Economic Empowerment. Pretoria: Department of Trade and Industry

**** Department of Trade and Industry. (2015). Broad-Based Black Economic Empowerment Act no.53 of 2003. Pretoria: Government Printer.

*** National Treasury. (2019). Economic Transformation, Inclusive Growth and Competitiveness: Towards An Economic Strategy for South Africa. Pretoria: National Treasury.

*** Republic of South Africa (RSA). (2004). Broad-Based Black Economic Empowerment Act. Government Gazette \# 25899. Cape Town, 1-6.

**** Republic of South Africa. (2018). Presidential Jobs Summit Framework Agreement, South Africa.

*** World Bank, (2018). An Incomplete Transition: Overcoming the Legacy of Exclusion in South Africa. Report No. 125838-ZA. Washington DC: The World Bank.

Submitted:

06.07.2019
Revised:

24.09.2019
Accepted and published online 26.09.2019 